УдК 340.12

A. М. Бернюков

\title{
ОСНОВНІ СУЧАСНІ ПОЛОЖЕННЯ ОНТОГНОСЕОЛОГІї ЮРИДИЧНОЇ РЕАЛЬНОСТІ
}

\author{
Основний висновок юристу: космос, світ, природа, \\ об'єктивна реальність, дійсність є елементами порядку. \\ Природне ж право є конституцією універсуму. \\ P. Марчіч ( Від держави закону до судової держави: \\ право як міра влади», 1957 р.)
}

Пролог

Сучасність називають добою великої перебудови нашого мислення. I це досить точне й невипадкове визначення існуючого інтелектуально-духовного середовища проживання на початку нового тисячоліття. Сучасному поколінню в усьому світі доводиться здійснювати досить серйозну методологічну переоцінку глобального характеру попередніх уявлень про буття реальності. В Україні ж усе це обтяжується важким минулим, зокрема тим, що в нас декілька попередніх людських генерацій послідовно зраджували високі ідеали правди.

Нині ж іноземний сатрап робить усе, щоб якомога дужче дестабілізувати стан справ у країні, спрямовуючи свої зусилля на ускладнення й без того нелегкої внутрішньополітичної ситуації. Його неприкрито підступні акції значною мірою спрямовуються на зрив наших державницьких процесів. Сили зла з новими потугами рвуться в бій із нами, щоб уже остаточно повернутися, навічно встановивши свою владу й запанувавши над світлом. Тому головна мета сьогодні - відвернути страшні часи смути, у якій чорна пітьма неістини може спуститися вже на весь світ.

Bcmyn

(постановка проблеми, оцінка стану літератури, мета, завдання статті)

Що існує взагалі? Як воно виникло? До чого прямує? I яким чином усе це пізнати? Подібні питання незмінно цікавлять людство, оскільки донині не вдалося безсумнівно й однозначно відповісти на них, хоча версій із приводу цього вже було висловлено безліч. Саме на такій невизначеності 
живе філософія. Причому вона стала місцем, куди було «скинуто» всі ці важкорозв'язувані проблеми. Щодо права «прима наука» розпочинається там, де закінчила працювати загальна думка, наштовхнувшись на важкодоступну для сприйняття концентровану юридичну матерію.

Сама ж юриспруденція вивчає право лише як факт. Філософське завдання при цьому - обгрунтувати таку частину дійсності. Причому мислителі, показуючи підстави цього явища, таким чином повинні обслуговувати сферу здійснення права в реалізаційному пізнанні життя людини. I все це - вирішення великого й специфічного методологічного питання про юридичну реальність.

Безпосереднім предметом філософії права є ідея јus, як їі зміст у належному, так і реалізація в сущому через lех, а далі - процес ії виконання в безпосередніх людських діях. Увесь цей статично-динамічний конгломерат утворює складну структуру. Він $є$ також тим, що ми називаємо юридичною реальністю. Визначення суті останньої спричинило величезний історичний спір про право, який триває досі. Саме в цьому питанні полягає ключова проблема всієї юриспруденції. Під праворозумінням можна розуміти зміст самого jus (його онтоархітектоніку) або ж сутність процесу пізнання юс (тобто гносеоідентифікаційність цього явища). Відповідно, юридичну реальність можна розглядати з таких же позицій, тобто і як онтологічний, і як гносеологічний феномен. Однак для охоплення всієї сутності цього поняття логічно допустити, що більш методично, грамотно й коректно робити це в комплексі таких підходів.

Зрозуміло, що під час вивчення стану дослідження проблеми насамперед піднімаються спеціалізовані та найбільш фундаментальні праці, зокрема й докторські дисертації, прямо чи опосередковано захищені за цією тематикою. Серед українських авторів таких робіт, на які логічно орієнтуватися, варто назвати, зокрема, А.А. Козловського [1], I.I. Котюка [2], C.I. Максимова [3] та М.М. Цимбалюка [4]. Однак у їхніх розвідках не надано вичерпних відповідей на визначені нами питання, оскільки ці вчені не ставили за мету дослідження саме буття юридичної реальності.

Серед зарубіжних авторів докторських дисертацій, виконаних у контексті аналізованої проблематики, можна назвати російських науковців А.В. Аверіна [5], Г.А. Гаджієва [6] та І.Л. Честнова [7]. Хоча й вони не досягли яких-небудь значних успіхів на ниві онтогносеології юридичної реальності. Вони не надали їй належну наукову оцінку фактично $з$ тих же причин, що й зазначені українські теоретики.

Визначаючи мету статті, ми виходили з того, що будь-яку інформацію необхідно не просто викладати як факт, а будь-яким чином обгрунтовувати iii в аспекті розгляду не наслідків, а причин. Сама ж констатація форми без з'ясування змісту вже не може задовольняти науку, тому варто поглибити пошуки. При цьому розуміємо, що філософськи глибоко осмислюючи јus, важливо не сказати, з яких норм воно складається, а пізнати й засвоїти його загальну сутність. Встановивши останне, саме юс можна легко деталізувати. Тому важливо пояснити, що робить «право правом». Це перед- 
бачає встановлення всього «підспідка» його буття, а не просто формальної комплекції. Тобто необхідно відповісти на певні питання, які неминуче постають із результату визначення лише формальних атрибутів: у чому полягає правовість јus? Навіщо воно існує саме так, а не інакше? Чим це обумовлюється та кому було потрібно його робити? Як взагалі право стало можливим? Хто $є$ його творцем та яким чином јus було сформовано? Що передувало цьому створенню? 3 яким початковим замислом воно утворювалось? Тому ми не обмежимось тим, що спробуємо зробити стратифікаційну розстановку юридичної реальності з визначенням їі компоновки, а принаймні запитаємо себе, чому вона має саме такий вигляд.

\section{Основні результати дослідження}

1. Між буттям та його пізнанням існує постійний тісний зв'язок, оскільки онтичний предмет постає для нас повсякчас лише в інтерпретації, завжди в безумовному порядку корелюючись відповідними суб'єктивними «поправками», викликаними нашими гносеообмеженнями в спробі відтворити для себе те, що досліджується.

Знання про об’єкт ми отримуємо лише тоді, коли пізнаємо суть його буття. І в цьому плані предмет у розкритті інформації про себе протистоїть нам. Відповідно, процес пізнання взаємовизначається в діалектичній парі «онтологія - гносеологія». I ця «планка» у своїй характерній опозиційності водночас є об'єднуючим фактором для інтерпретатора 3 досліджуваним. Тому буття-для-нас - це існування-в-пізнанні, де Гносео - перехідник між суб'єктом і світом, що показує його співпричетність до Онто.

Відтак людина як суб’єкт - це взаємопов'язуюча ланка онтології з гносеологією. I цей ланцюг діє завдяки пізнанню в цілому та нашим намаганням осмислити юридичну реальність зокрема. В останній праворозуміння - це типова онтологічна та гносеологічна проблема в їх взаємозв'язку. I це дуже важливий висновок, що має величезне практичне значення.

Таким чином, взаємозумовленість онтології та гносеології є центральною, провідною філософсько-теоретичною передумовою також пізнавальних процесів буття права. У юридичній реальності це виявляється в певних моментах. По-перше, за своєю онтологією право є об'єктивним, а за гносеологією - інтерпретативним, тобто суб'єктивним. По-друге, існує jus ідеальне, є його образ також у нашому мисленні (зокрема, уявлення в позитивних законах). Засобом же відображення досконалої правової форми належного у світі сущого виступає саме «гносео».

2. У вирішенні конкретного юридичного випадку важливими є як онтологічні складові, так і гносеологічні діï щодо їх отримання. Яка норма јus naturale має бути гіпотетично використана як вказівник для вирішення це «питання буття», натомість безпосереднє іï застосування в конкретиці справи людиною $є$ вже суто «пізнавальним предметом».

Отже, питання про те, чим є право та як його пізнати, є основоположними питаннями юриспруденції, а всі інші - лише їх продовженням. Тому онтологія та гносеологія права - дві сторони однієї юридичної реальності. Решта носить допоміжний характер, постає з них. При цьому наявність 
незліченної кількості дефініцій права у філософії, соціології, культурології, самій юриспруденції відображає не стільки розбіжності між його дослідниками, скільки змістовне різноманіття цього фундаментального буттєвого феномена. До того ж кожна історична епоха пропонує свою концепцію розуміння jus. Тобто право в онтологічному плані існує лише одне, а його гносеологічних інтерпретацій є безліч.

Головне ж методологічне завдання для всіх нас, таким чином, постає в тому, що необхідно як у теорії, так і на практиці пов'язати об'єктивне значення права 3 автономією його інтерпретації, тобто встановити точку примирення в єдності між юридичними онтологією та гносеологією.

3. Сама ж правова проблема виникає через присутність «іншого», який неминуче втручається в-мій-світ. У цій опозиції протистояння екзистенцій обумовлюється вже тим, що поруч є Ти як хтось Не-Я, тобто інакший від моєї егонатури, зі своїм баченням, відмінним від мого. При цьому особливості Наших самостей не збігаються. I тут «Інші», яких називають так, щоб підкреслити свою сутнісну неприналежність до них, посягають на Мене. Так чи інакше, усі Вони прагнуть здійснити вторгнення в Мою свободу, прагнучи за рахунок цього розширити свою. Тому коли виникає зв'язок із Чужим, то постає дилема впорядкування різних екзистенційних видів буття. Моє і Твоє повинні взаємно узгодитись. Адже чужий ніколи не стане «я», і навпаки. Власна екзистенція не обернеться на іншу.

Саме спільним проживанням Інший, а також Я в буттєвому середовищі існування-кожний-в-своїй-екзистенції протиставляються. Присутність саме поряд Чужого/Не-мого автоматично детермінує для Нас обох напруження: одна абсолютна свобода зіткнулась з аналогічною за можливостями. Відтак у бутті-з-Іншим Ми обоє екзистенціонуємо, змушено трансцендуючи до витоків права (як онтонорм самого Життя) у належне, у якому й шукаємо обгрунтування меж Його-і-Себе. Саме jus naturale у разі входження в міжсуб'єктний контакт здійснює перетворення такої взаємної зони обопільного не-комфорту на розумну систему компромісних поступок один іншому. Інакше відбувалося б знищення певної екзистенції. Порушення правил такого співжиття фактично є дією не за правом. Тому недотримання jus naturale єдино можливе лише тоді, якщо відсутній поруч Інший.

Відтак необхідність у праві зумовлюється наявністю не обмеженої природною свободою екзистенції. Спільне ж існування таких максимум завжди утворювало конфлікт, численні суперечності, які потребували свого вирішення. Кожне «Я» як інакшість неминуче протистояло буттю Іншого, що саме спричиняло й підтримувало постійну напругу протистояння в суспільстві. Визначення меж світів екзистенцій стало першою потребою, щоб суспільство не зруйнувалось та продовжило свій розвиток. Спілкування із собі подібними зі спірних питань стало нерозв'язуваною справою. Тому зняття цієї постійної напруги вимагало наявності єдиної для використання всіма членами соціуму вимірювальної «рулетки». Відтак з'ясувалося, що кожний має самообмежитись, віддати частину своєї свободи на користь формування спільної. Тому саме право стало виходом із такої 
ситуації суперечок, що була зумовлена дефіцитом узгодженості в умовах постійного соціального «тертя». Пізнання ж jus naturale зумовило процес формування нами юридичної реальності.

4. Головний зміст права - це встановлення необхідної рівноваги між свободою екзистенцій, максимально можливе, найбільш оптимальне співузгодження основ загального й одиничного в спільному проживанні. Утвердження такого компромісного порядку, за якого реалізація індивідуальної волі не завдавала б шкоди солідарності, є умовою співіснування. 3 іншого боку, друге не має здійснюватись за рахунок пригнічення першого. Тобто завдання права полягає в забезпеченні самореалізації можливостей особи так, щоб вона не пригнічувала екзистенційні межі «чужих». Таким чином не порушувався б колективний союз усіх осіб, поєднаних одним простором і часом проживання. У цій мірі розумності як вияву природної справедливості знаходить своє вираження повага до святості автономії індивідууму в його гетерономних відношеннях до ближньої особистості.

Право за своєю структурно-функціональною сутністю є згрупованим комплексом відмежованої вибіркової множинності однотипних елементів належного, які у своїи інтегрованій онтозалученості перебувають в узгодженій взаємодії, становлячи сукупну єдність впорядкованого цілісного утворення. Перебуваючи таким чином в одній площині відношень і володіючи відносною самостійністю, стійкістю й автономністю свого функціонування в зовнішньому середовищі сущого для досягнення чітко заданих цілей, право отримує характер визначеної спрямованості на створення найбільш ефективного сфокусованого результату нормативного врегулювання міжсуб'єктних відносин для цього виду буття.

Право у формально-лінгвістичному плані - це не просто реферативно-дескриптивний, номінативний диктум як конкретний контенсив-інструкція необхідної поведінки, у ньому безпосередньо виражається ставлення ментального посилу до свого адресата. Тобто jus naturale постає як модальний план ергативності дій свого творця для суб’єктів-виконавців.

5. Право живе саме по собі лише тією мірою, наскільки дозволяє ступінь його входження в загальну структурну систему буття. При цьому воно посідає лише своє, відведене та вказане йому місце, у якому є повноправним господарем. Лише право відповідає за свою ділянку. Надане йому завдання полягає в тому, що воно покликане унормувати людські відносини найбільш адекватним, ідеальним чином. Жодна інша ідея не наділяється такими «симфонічними» повноваженнями в цій галузі. Тому право - це найбільш оптимальна модель гармонічного врегулювання суспільних відносин у всьому бутті. Воно було створене до й саме для людини та залишиться чинним після нас. Відповідно, повстати можна проти державного закону, проте не проти права.

Універсальність права полягає в тому, що воно передбачає регулювання всіх суспільних відносин, оскільки створюється самим логосом буття. У зв'язку із чим ці правила вбудовано в саму суть світу. Тому не може відбуватися такий вчинок чи бездіяльність суб'єкта, щодо яких відсутня 
вказівка в суто «космічному» jus naturale. Тому лише те має вважатись правопорушенням, що йде в розріз зі змістом такої норми: «Ти тут, у бутті, отже, мусиш діяти за встановленими правилами місця свого онтоперебування. Зі своїм уставом у чужий храм не ходять. Не хочеш проблем дій за правом. Інакше відбувається відплата через те, що не діяв за јus naturale. Усе вчинене всупереч останньому зрикошечує в тебе самого ж».

6. Отже, право в цілому - це стійкий світопорядок, покликаний забезпечувати спільне існування людей у мирі, відповідно убезпечуючи їх від колізій інтересів групи й особистості, бездоганно вирішуючи (у плані досягнення справедливості конкретного випадку) конфлікти проблем розподілу, що виникають на цій основі. Вирішення такого завдання відбувається через досягнення відповідного компромісу. Усе це для дієвого виконання в сущому з необхідністю передбачає потребу в інстиціюванні юридичних процесів зі створенням відповідних суспільних (державних) органів, в ідеалі підвладних лише здійсненню ідеї jus naturale.

У свою чергу онтологічно jus naturale являє собою сукупність юридичних норм одного змісту, натомість у гносеологічному аспекті - звід правил, що містить у собі безмежне коло можливих суб'єктивних значень. Однак серед останніх усі є неправильними, за винятком того єдиного, що спочатку є буттєво сформованим та автентично закладеним у світ. Тому завдання людини - зупинитися саме на цьому єдиному. Сьогодні $€$ всі підстави вважати, що саме jus naturale варто розглядати як постійно діючу ідеальну систему загальнообов'язкових правил поведінки, закладену в основу існування всього нашого буття в частині функціонування в ньому суспільства. Значення цих норм не залежить від суб'єктивної згоди, а отже, і від позитивних законів. Ці вимоги лежать в основі наявного світового порядку, визначають його: сама природа речей, людини й життя постає 3 них. I лише воно є основною підставою для оцінки чинних нормативно-правових актів та всіх інших процесів, що здійснюються в юридичній реальності.

7. Спочатку jus як сукупність ідеальних норм, вироблених для буття, існувало «саме-в-собі», було незатребуваним, тобто поставало лише як чиста правова реальність. Коли ж ми нею «зацікавились» у спробі іiі проявити з метою адекватного врегулювання наших суспільних відносин, то розпочалась гносеологія јus, приєднавшись до його онтології. Таким чином, з'явилася дійсність, створена нашими пізнавальними зусиллями з відповідною спробою побудови на живильній енергії змісту jus, те, чим воно «обросло» завдяки суб'єктивності та стало юридичною реальністю.

Отже, що ми, зрештою, маємо? Юридична реальність - це саме јus naturale та те гносеологічне поле, яке функціонує навколо нього, постаючи у вигляді засвоєння суб'єктом дійсності в системі правових категорій та інших відповідних інтерпретаційних дій, що знаходять свій завершальний вияв у нашій безпосередній суспільній поведінці.

Додатково можна зауважити, що за своєю кінцевою структурою, у якій виявляється іiі конкретний зміст дії, юридична реальність є буттям, сфор- 
мованим суспільством у результаті пізнання права шляхом його зовнішнього відтворення через формування своєрідної локалізованої системи інтерпретації у вигляді спеціального механізму генетично пов'язаних явищ у розгалуженості їх зв'язків з іншими спорідненими феноменами й фактами дійсності, які з них постають. Основними частинами цієї конструкції виступають саме jus naturale (як базисний фундамент) та законодавство (ii «несучі стіни»). Відповідно, до елементів цього онтогносеологічного феномена належать насамперед правосвідомість, порядок, охоронні й застосовні органи тощо, тобто все те, що пов'язане з пізнавальним процесом реалізаціі права в нашому соціумі. Водночас важливо в такому аспекті зробити певне зауваження щодо структури цього явища: якщо ми говоримо «правовий», то маємо на увазі онтологічний рівень (тобто чисте юс), а коли вживаємо поняття «юридичний», то розуміємо гносеологічний ярус (як знання про jus naturale разом з останнім у вигляді основи для їх отримання) цієї системи.

8. Наведене дає нам можливість сформувати визначення правових онтології та гносеологіі, давши їм відповідне належне наукове й філософсько-методологічне обгрунтування.

Таким чином, правова онтологія - це наука про буття јus, його внутрішній зміст і форму існування в суспільстві у вигляді окремої реальності як сукупності функціонування відповідних феноменів у соціумі. При цьому, розкриваючи основну сутність юридичних явищ, вона має допомагати індивіду краще орієнтуватися під час реалізації норм як складного гносеологічного процесу. Ця обставина виявляється вкрай важливою для всіх без винятку, адже перед будь-якою нашою дією, відповідно до сукупного сенсу правового життя, його попередньо завжди доводиться з'ясовувати. I краще це робити адекватними методиками, тобто підходами, сформованими саме правовою гносеологією. Визначення ж останньої, на нашу думку, може мати такий вигляд: правова гносеологія - це філософсько-правове вчення, у якому вивчаються всі важливі юридичні проблеми, що стосуються загальних умов, сутності пізнання jus, можливості, межі й характеристики цього процесу, його форми, рівні та численні різноманітні відношення, пов'язані з ними, а також досліджується достовірність отриманих таким чином відомостей у комплексі з критеріями їх істинності.

Відповідно, правова гносеологія відображає всю сукупність явищ юридичного характеру, існуючих у тому чи іншому суспільстві, спрямованих на пізнання jus. До неї ж варто віднести здійснювану згідно із цим нашу поведінку. Адже процес пізнання права - це також спроба суб'єкта на практиці залучити осмислені ним норми належного в сущому.

9. Саме правопізнання - це випробування таємничістю, постійний тривожний «дотик» до більш витонченого, цілком оповитого «димкою невідомого», інтелектуально безмірного, зрештою, зустріч зі змістом світобудови, власною обмеженою гносеологічністю, що завжди піднесено захоплює. Контури «силуету», у яких огорнуто jus naturale, повсякчас намагаються сховатися за обрисами горизонту непізнаного, тим самим сповіщаючи про 
безкінечні напружені блукання мислення, які чекають на нас попереду, у прямуванні до майбутнього. Причому право, як і реальність, що нею визначається, побудоване на гносеопроцесі юридичного буття (у якому герменевтика відповідає за перебіг цієї процедури, а епістемологія - за ії якість). Усе це обумовлюється тим, що jus naturale не дано нам як фізична даність, а існує для людини лише у вигляді її динамічної дії-з-осмисленняюс. Основні чинники, якими об'єктивно характеризується пізнання правової дійсності, можна звести до наведених далі положень.

10.1. Призначення ідеї jus naturale - бути вичерпним світофундуючим фондом-звідом бездоганно дієвих правил як об'єктивно створених інструкцій, безпосередньо вироблених для підтримання самого Життя. Воно функціонує саме за відведеними йому правилами як один з онтозаконів, йому достатньо того, що воно існує за власною природою, зі своїм чітко визначеним місцем перебування, виконуючи індивідуальну роль щодо виконання відповідального завдання. Jus naturale особисто активно не поривається в людське мислення (хоча постійно реалізується, автоматично корегуючи, підправляючи наше життя в бік встановленого балансу в природі), проте завжди готове для проявлення-реалізації в ньому, при цьому будучи тим, що є зручним для пізнання лише розуму, який досяг відповідного рівня. Тобто право проявляється в думці повною мірою лише тому суб'єкту, який спромігся отримати буттєво-відфіксований, чітко встановлений, конкретно визначений певний формат відповідного й достатнього високого мислення. Унаслідок цього людина, лише постійно розвиваючи свою технологію юридичного «гносео», отримує можливість усе більше «дотягнутися» до права, а отже, перед нею все ширше розкривається зміст онтології останнього.

10.2. Незважаючи на це, право як продукт думки світостворювача байдуже чи нейтрально ставиться до наших творчих потенцій щодо відкриття свого змісту. В онтологічному плані воно постає для-себе-таким-яким-є, будучи гносеологічно відкритим і закритим водночас (не ворогом нам, проте й не другом), існуючи насамперед саме-по-собі-і-в-собі, однак у своїй місії будучи призначеним суб'єкту (будь-якій утвореній Тут субстанційній формі розумного мислення). Для нього справа пізнання з боку інтерпретатора - це власні проблемні клопоти самого дослідника, які јus не стосуються. У права своє призначення - містити в собі вищою мірою якісні правила суспільного врегулювання-впорядкування-внормування та за адекватним гносеологічним запитом сповістити-надати-показати-відкрити їх. I воно його знає. При цьому јus naturale ніби уповноважено промовляє нам від імені онтоЦілого, сигналізуючи такою вказівкою в описі необхідної умови людського існування: «Хочете пізнати мене, мати у своєму розпорядженні (а це у ваших же інтересах як буттєво перша соціальна потреба колективного співіснування в сущому для всіх вас) - дійте самі, я не буду протидіяти чи заперечувати цьому (навпаки, саме для такого «бібліотечного» використання-для-вас, у розгортанні й полягало моє створення), проте й допомагати також. Яких докладете зусиль, таке й отримаєте пропорційне розуміння мого змісту. Зможете це зробити (пройти це гносеологічне випробування) 
як те, що лише вимагається світовим космічним місцем-середовищем перебування-поселення-розташування, у яке ви виявились закинутими силою Вищою руки, - вцілієте, виживете, досягнете результатів, підніметесь на вершину. Якщо ж ні (не зможете впоратись), то шляхом еволюційного відбору на заміну вам прийде інший, більш гідний у цьому плані вид суб'єкта. Маятник темпорального рахування в годиннику зупиниться навічно лише для вас, проте час продовжить свій великий невпинний забіг (відведений для руху існуючого виду онтичності) далі, планомірно розвиваючи буття. Місце вибулих (замість вас) займуть значно прогресивніші в гносеологічному плані». Тобто в пізнанні jus naturale людина паралельно має довести й захистити надане їй право на життя, з'ясувати, чи потрібна вона далі в цьому світі. Таке відстоювання наданої нам авансом можливості на існування, у якій юс виступає паролем усіх наших суспільних вирішень, є еволюційним відбором найвищого рангу. Це екзамен на право називатися суб'єктом.

11. Відтак роль людини в юридичній реальності зводиться до виконання вже підготовлених для неї в бутті приписів права. Тому при цьому вже не потрібно «видумувати свій велосипед». Реалізувати норми права - це все, що вимагається від кожного із суб’єктів. Однак кінцевий вибір все-таки залишається за людиною. Вона сама мусить вирішити для себе, чи робити все за правом. Тому jus naturale $є$ підготовленим для розуміння людини. Однак усе залежить, знову ж таки, від їі бажання й докладених нею зусиль із пізнання права.

У самій юридичній реальності гносеологічно завершений процес - це прояв трансгресивного трансцензуса до Абсолюту через скидання умовностей у точці біфуркації з гіпостазуючим відкриттям нового когнітивного горизонту у вигляді простору всіх можливих аттрактів як буттєво-правових змістів. Фактично це вихід за межі соціального буття та досягнення зовнішнього спостерігача щодо досліджуваного феномена, тобто гносеологічний рух, спрямований на зайняття стійкої онтологічної позиції саме щодо jus. Цим актом нейтралізується влада позитивного права, яка «пов'язала» міцними «оковами» наш багато в чому схоластичний розум. При цьому також усуваються стійкі соціокоди як апостеорно вкорінені в людині умови існування нашого мислення, емпіричного за суттю в сущому. Тобто це радикальна трансформація індивідуальної свідомості й виведення з ладу системи субординаціі обраних для нас суспільством функцій, у результаті чого усувається нав'язаний нам владний контроль, знімається «експропріація» дійсних життєвих орієнтирів людини та відбувається повернення правового першопочатку. Тим самим робиться «щеплення» від оманливості беззаперечності й непохитності створюваних соціумом нормативних конструкцій як істин в останній інстанції.

11. Основною діяльністю в юридичній реальності виступає процес інтерпретації jus naturale в проекції на фактичні обставини, тобто в умовах, здійснюваних під час вирішення конкретної справи. При цьому необхідно точно й дозовано, ніби аптекар, вираховувати «одяг» права на випадок. У цьому розумінні юриспруденція - математика в гуманітарних науках. 
Сама ж юридична кваліфікація як гносеологічний акт з'ясування - це складна комбінаційна вправа для суб'єкта, у якій насамперед впізнаний ним факт вказує на право. У свою чергу ідентифіковане jus naturale знову зворотно повертає (необхідно скеровує) у своєму застосуванні-уточненні до фабули справи. Лише таким чином, через шаховий алгоритм неодноразового повторювання, у спрямовуванні від факту до права й навпаки, у ситуації постійного вибору, реалізується юридична ідея.

12. Для вдосконалення будови юридичної реальності в нашому соціумі необхідно провести низку невідкладних заходів як теоретичного, так і організаційного характеру з метою покращити й гармонізувати механізм іï діï.

Однак насамперед варто чітко відповісти на питання про те, яку державу ми хочемо побудувати: правову чи позитивістську. Зрештою, необхідно відпрацювати більш досконалий механізм юридичного розуміння, оскільки колишня система чітко показала свою неефективність. Суб'єкти виконання норм відчували себе в ній не пов'язаними jus naturale, що спричиняло відомі негативні наслідки. Також необхідно остаточно визначитись із тим, що нам потрібно, або й далі лише говорити щодо того, що варто робити для поліпшення нашої юридичної реальності: лише цим не обмежуватися чи реально діяти.

13. Нині важливо насамперед заспокоїтись, «зняти градус» існуючої «напруги» в суспільстві в питанні досягнення нами юридичної істини. Для цього варто звернутися до стратегічного проектування програми психолого-екзистенційних умов гармонізації соціально-правової ситуації розвитку в Україні, моделювання «ідеальної» схеми динаміки прояву своєї ідентичності суб'єкта, розгляду можливих варіантів та обгрунтування шляхів такого переходу, методологічно спираючись на парадигмальний підхід культурної антропології. Усе це дозволить відновити в категоріальних «правах» таку універсалію, як jus naturale, та остаточно подолати безальтернативність опозиціоністського дискурсу позитивізму у сфері юриспруденції. Зі зверненням до досвіду буття та його констант, особливо на психологічному рівні, за збереження того цінного, що вже є в соціумі, можна пов'язувати перспективи просування до повноти природи «суб'єктом життя».

Необхідно, щоб у законах у цілому закріплювався такий юридичний статус людини, який створював би найсприятливіші умови для ії всебічного й гармонійного розвитку, дозволяв би кожному бути творцем своєї долі, самостверджуватись як особистості, активно брати участь у справах суспільства та держави. Саме із цих мотивів нормативно-правові акти по суті справи мають виступати як втілена в лаконічних суворих нормах справедливість. Проводячи послідовну й неухильну лінію втілення в життя веління jus naturale, зміцнюючи режим максимально можливого розвитку екзистенції, держава забезпечує торжество буттєвої істини, сприяє утвердженню найгуманніших відносин між людьми.

14. Сьогодні в нашій юридичній науці інтенсивно відбувається ломка старих, позитивістських уявлень про право, у зв'язку із чим спостерігається болісна переоцінка цінностей. Те, що це усвідомлюється, уже добре. 
Однак викликає серйозну тривогу інше: чи надовго нам вистачить такого пориву для продовження прогресу в цій сфері? Чи не піддамося ми знову на солодкі вмовляння позитивізму? Ось що головне. Адже й нині в нашій науці в особі юрпозитивізму існує думка (від якої ми ніяк не спромоглися повністю дистанціюватись), згідно з якою закон і $є$ правом. Зрозуміло, що з такою позицією сучасне здорове мислення не може погодитись, оскільки вона не відображає реальний стан справ. Тому необхідно остаточно й безповоротно «вирвати» наші думки із цього «болота» абсолютного юрпозитивізму, «трясовина» якого все більше нас засмоктує, та обмежити себе від подальших його рецидивів.

Також важливо на практиці підтвердити наш категоричний намір поглиблювати позитивні зміни й розвивати досягнуті важливі успіхи в якісному перетворенні правового мислення. У зв'язку із цим необхідно створити усталену атмосферу розуміння того, що кроки назад у цій відповідальній і життєво важливій справі не прийнятні. Це має бути для всіх непорушним принципом. Важливо також, щоб суть, призначення й характер того фундаменту, який утвердиться на праві, не були уявними, тобто здійснювались не на словах, а на ділі, не в широких деклараціях, а в конкретній реалізованості та використанні в галузі управління суспільством і державою.

15. Сучасна вимога часу є такою, що варто позбутися домінуючої в нас схильності до волюнтаристсько-персоналістського режиму влади. Лише право під час його впровадження здатне знеособлювати державний механізм. Останній має виступає лише звичайним робочим знаряддям, «без фарб», для досягнення загального блага, працюючи винятково на потреби й запити соціуму, а не на «пузо» можновладця. При цьому головна небезпека криється в тому, що ніхто не може впевнено заявити, що пізнав право в усій його вичерпності, до самого кінця. А тому радикальне запровадження єдиних стандартів, тотальну підгонку під жорстко уніфіковані правила, єдину «стрижку» для всіх у юридичній сфері не може бути підтримано.

Побудова правової держави - це торжество демократії, яка має долучити всіх членів суспільства до добровільної й активної участі в небаченому досі підйомі юридичного мислення та подальшій боротьбі за підвищення його якості, оволодіння всіма багатствами культурної спадщини попередніх епох і створення нової, сучасної культури пізнання јus naturale.

16. Немає нині більш важливого завдання, ніж утвердити в нашій державі авторитет јus naturale. I для цього необхідно зменшити вплив позитивізму на формування нашої правової поведінки за рахунок збільшення орієнтування саме на юс. Змішувати, тим більше підміняти останнє законом, неприпустимо, оскільки це веде до порушення збалансованості процесів юридичної реальності, їі свідомого деформування. У зв’язку із цим переступити за грань суто юрпозитивістського мислення означає відкрити прямий шлях до встановлення правопорядку.

Водночас не може не викликати здивування той факт, що розширення юснатуралізму іноді (хоча вже менш повсюдно) розглядається як «анархізація» юридичної науки. А зв'язок природних правових початків із законом 
розцінюється як недолік та надлишки гуманізації. У зв'язку із цим необхідно зазначити, що заперечення регулювання суспільних відносин методом твердої диктаторської державної руки як невидимої, єдино праивльної спрямовуючої сили - аж ніяк не випадкове явище на сучасному етапі розвитку нашої цивілізації, а прояв суто демократичних процесів у світовому суспільстві.

Ідея гуманізації є частиною загальної тенденції лібералізації сучасного суспільства, закономірної трансформації його пріоритетів в умовах постіндустріальної держави: «відмирання» моральності авторитарного типу, у межах якого влада в односторонньому порядку, спираючись лише на себе, визначає, що добре для людини, і в одноособовому порядку встановлює норми нашої поведінки. На противагу цьому, позбуваючись практики соціальної зарегульованості, кожний індивід поступово стає господарем самого себе. У цій денормативізації екзистенція повертає собі волю, однак збільшує свою особисту моральну відповідальність перед буттям.

17. Що стосується найважливіших юридичних критеріїв, то вони повинні бути універсальними, комплексними та єдиними для всієї «світової карти права», інакше вона може стати спотвореною на догоду мапі політичній. Ідеологічні напластування, які привносить суб'єктивність, те, чим обростає пізнання в кожному соціумі, не повинні затуляти собою юридичну основу. У результаті цього позитивізм, що несе із собою теоретичний рівень осмислення гносеологічного образу юснатурального права, виявляється зовсім не зайвим за такої ситуації. При цьому він має бути зовсім позбавленим ідеологічного навантаження, такого звично притаманного йому в передозуванні в нас сьогодні. А тому правильніше говорити не про юснатуральний або юрпозитивістський напрями дослідження в юриспруденції, а про структурно-системний, оскільки комплексом є також сама юридична реальність, а кожен із зазначених філософсько-правових напрямів зосереджує свій потенціал лише на одній із іï частин.

Відтак жодну із цих методологічних «програм» не може бути визнано абсолютною, хоча в сучасному пізнавальному процесі юридичної реальності ми повинні в цілому віддати перевагу саме юснатуралістському методу як такому, що переслідує мету проникнення в первинну матерію права. Обов'язкова ж присутність позитивістського елемента, який не усувається, пов'язана з необхідністю об'єктивації jus naturale для більш придатного його сприйняття в суспільстві. Тому право й закон складають центральні рівні юридичної реальності, при цьому перше завжди має виступати безумовною основою для створення другого.

Право в «оправі» закону має вигравати як алмаз. У цьому плані питання про поєднання jus naturale iз lex є онтологічним за формою, проте гносеологічним за змістом. Важливо, щоб юрпозитивізм діяв у синхронному й нерозривному зв'язку з юснатурале; лише тоді можна досягти гармонії в проектуванні та вибудовуванні юридичної реальності, у якій право (як «онто») збігалося б із нашим його розумінням (як «гносео»).

18. Водночас було б несправедливо стверджувати, як це в запалі полеміки іноді роблять деякі юрпозитивісти, що в юснатуралістських напря- 
мах вивчають лише субстанцію права, абстрактну від реальності. Говорити так - створювати метафізичний розрив опосередкування речей і їх відносин, форми та змісту. Правильне розуміння права як адекватне встановлення його сутності - це необхідна умова адекватного застосування јus. Інакше кажучи, гносеологія повинна з'єднатися в такому відношенні з онтологією.

Фактичне заперечення позитивістів юснатуральному праву як дозаконодавчих норм має своїм джерелом недовіру до абстрактного. Цілком виразно це знаходить вираження в тому, що юриспруденція в безпосередній практиці оперує саме конкретними правовими суперечками як фактами реального життя. У зв'язку із цим доречно пригадати, що не лише немає абстрактного без безпосереднього, а й навпаки. Інакше кажучи, конкретне тому $є$ конкретним, що воно є синтезом багатьох визначень, відповідно, єдністю різноманітного. У мисленні воно виступає як процес і результат.

Конкретне ж без абстрактного існує не як результат інтерпретації, тобто знання, а як щось безпосередньо дане в чуттєвому досвіді, почерпнуте із сенсуалістського джерела. Найбільш характерно це проявляється саме в абстрактності правових норм, які під час реалізації повинні проектуватися на конкретику юридичного випадку.

19. На підставі вказаного варто мати на увазі, що принципово важливо надати більшої ваги й значення саме праву як головному регулятору нашої поведінки. Натомість закон необхідно завжди перевіряти правом, адже перше - це лише відображення другого. I це «відбиття» може бути неправильним. Тому головна вимога до реформування юридичної реальності в нашій державі (без жодних винятків) - це формувати всі нормативно-правові акти обов'язково лише на основі положення jus naturale. Необхідність дотримання права має бути безумовною. Норми јus naturale як основоположні принципи нашого буття повинні свято виконуватись, тому необхідно рішуче присікати будь-які відступи від них, а за одну лише пропозицію їх обійти вже необхідно судити. Адже в праві закладено найважливіші фактори зміцнення суспільного ладу. Тим настійніше необхідно висунути тверде гасло все більшого розгортання положень jus naturale в соціумі та втілення їх у наше безпосереднє життя шляхом відповідного нарощування знань.

Необхідно розглядати постійну турботу про подальше зміцнення права як один із найголовніших важелів успішного вирішення великих завдань суспільного будівництва. Для цього варто виробити відповідну стратегію нашої держави, яку можна реально здійснити, з метою ії динамічного й пропорційного розвитку. Відповідно, необхідно створити довгострокову й діючу програму подальшого будівництва позитивної частини юридичної реальності, а також чітко визначити головні напрями діяльності держави в цій сфері, водночас вирахувати всі недоліки, що заважають нашому руху вперед, і сформувати шляхи й методи їх протидії та подолання. При цьому виконання такого плану вимагає безумовного підвищення відповідальності та юридичної культури кожного суб'єкта правозастосування, докорінного поліпшення організації й удосконалення методів їх роботи. 
20. Таким чином, вимоги часу диктують необхідність серйозних перетворень усієї системи нашого правозастосування, насамперед поглиблення в ньому демократичних начал, глибшого вивчення фактичних обставин справи, посилення домінування jus naturale над позитивними нормами, тобто превалювання духу першого над другим тощо. Необхідність цього переконливо підтверджується аналізом причин правозастосовних помилок. Зокрема, як показує практика, більше половини їх, які призвели до необгрунтованого засудження громадян, були викликані саме хибним розумінням jus naturale. При цьому в нас часто правозастосувачі стають саме владоохоронцями, а не зберігачами «вогню» права.

Негативно впливає на ефективність правозастосування також укорінена практика прийняття рішень про пряме політичне втручання в неї «згори». При цьому мова йде насамперед про Конституційний Суд України, який із самого початку став «ручним» знаряддям, перетворившись на маріонетку для найвищим посадових осіб держави, щоб вони змогли узаконити партійні інтереси та свої особисті амбіції. Однак усе це серйозно підриває престиж нормореалізатора, свідчить про те, що політика перемагає право.

21. Як уже було зазначено, одна з архіважливих цілей правозастосування - забезпечення справедливості, а отже, і створення соціального благополуччя всіх нас. Відповідність нормореалізації морально-етичним уявленням суспільства має базуватись на дійсних гносеологічних факторах розуміння всієї юридичної реальності. В окремих хибах такого виду інтерпретації проявляється індивідуальна несправедливість рішень. Поширені помилки зменшують соціально-буттєву справедливість правозастосування в цілому. Проте особливо негативне значення мають сформовані в нормореалізаційній практиці деякі загальні підходи, зокрема ті з них, які жодним чином не виправдовуються з точки зору саме духу jus naturale (наприклад, випадки засудження за дії, які лише формально підпадають під ознаки злочину, а насправді вони в умовах, що були вчинені, є суспільно корисними; некритичне ставлення служителів Феміди до матеріалів попереднього слідства та низка інших проявів обвинувального ухилу суду). Крім того, варто відзначити в цьому аспекті також помилки, викликані широким застосуванням несправедливих покарань із точки зору скоєного. У низці місць соціально-юридична справедливість підривалася також прямими зловживаннями чисто суб'єктивного, волюнтаристського характеру.

За цих умов необхідність придбання достатнього знання розуміння юридичної дійсності вже не може бути поставлено під сумнів, а концепція професійного осмислення jus naturale повинна точно та ясно націлювати практику на виховання правового мислення, орієнтованого на найважливіші цінності сучасного співтовариства: безпеку людського роду, розвиток світової культури, загальнолюдський гуманізм, ненасильницький соціум, адекватний порядок у суспільстві для розвитку в ньому кожної особистості тощо. Таке велике переосмислення має підкріплюватись у державі реальними справами. 
22. Вважаємо, що закріплення в законі як однієї із цілей правозастосування твердження про справедливе вирішення справи сприяло б вирішенню важливої для нашого суспільства проблеми досягнення юридичної істини. Природно, що на забезпечення встановлення останньої в цілому повинні спрямовуватися також практичні заходи щодо перебудови створюваної нами дійсності в цій сфері. Однак насамперед для підвищення ефективності правозастосування важливо всебічно представляти умови, якими воно забезпечується. Очевидно, що одна з них - правильне розуміння јus naturale. Іншою важливою умовою ефективності правозастосування є законодавство, яке формулює його мету. Воно має містити необхідні правові засоби іï досягнення. Не викликає жодних сумнівів також те, що дієвість правозастосування може забезпечуватися лише тоді, коли воно здійснюється на основі процесуальних норм, що відповідають саме jus naturale. У свою чергу це передбачає не лише юснатуралістську обумовленість таких цілей, а й правильний вибір методів їх досягнення. Водночас важливим $€$ також пошук рішень, спрямованих на вдосконалення позитивних норм відповідно до мінливих суспільних потреб. Доцільність подібних законодавчих змін певною мірою підтверджується практикою використання так званої вільної інтерпретації Європейського Суду. Такі нововведення багато в чому сприяли б усуненню правозастосовних помилок (в аспекті неможливості передбачення виникнення всіх можливих відносин у суспільстві, що підпадають під нормативне регулювання).

23. Окремі важливі пропозиції й рекомендації можна спеціалізовано віднести також до сфери правосуддя. Одним з основних і визначальних завдань при цьому є зміцнення кадрів, укомплектування фахівцями, здатними виконати свої відповідальні обов'язки. Важливо в цьому сенсі не лише забезпечити підбір професійно підготовлених і бездоганних у моральному плані кандидатів, а й врахувати їхні психологічні можливості для здійснення своєї діяльності. Потрібні також спеціальні заходи, спрямовані на підвищення принциповості суддів, їх здатності приймати рішення, засновані саме на юсприродних і деполітизованих засадах. Особливої уваги від служителів Феміди вимагає формування сучасної правосвідомості, засвоєння ними сутності перетворень, що відбуваються в нашій країні. Цей пробіл потребує заповнення кадрами, які не лише вміють аналітично мислити, а й володіють якостями тонкого відчуття юридичної істини. Необхідно забезпечувати також високі ідейні якості суддів і їх здатність здійснювати функції незалежно від будь-яких впливів, справедливо, безпристрасно й об'єктивно.

Очевидно також те, що, крім досягнення повної неупередженості, важливим $€$ подолання формально-бюрократичного характеру управлінської діяльності, тобто іï переорієнтація з дріб'язкової опіки «храмів Феміди» й інвентаризації недоліків на здійснення заходів із досягнення реальних результатів, здатних дійсно змінити стан правосуддя на краще. Робота, що проводиться в межах керування третьою гілкою влади, повинна спрямовуватись на забезпечення ефективності вирішення юридичних справ, 
насамперед на зміцнення «правовості» їх розгляду. Основний наголос при цьому варто перенести на виявлення й поширення позитивного досвіду ведення процесів та організації роботи взагалі. Таким чином, однією 3 головних проблем управління в цій сфері $€$ створення умов для повного й послідовного проведення в життя основоположних принципів сучасного судочинства. Останнє ж, і про це не можна забувати, - складна, високовідповідальна галузь державної діяльності, відповідно, підвищення їі ефективності передбачає активне проведення багатопланових заходів.

24. Водночас зрозуміло, що викладені висновки в частині розбудови юридичної реальності є справедливими лише для суспільства, відкритого для демократичних змін. Там же, де існує «телефонне право», «домашнє законодавство» й «кишенькове правосуддя», усі політико-правові процеси підкоряються лише волі тоталітарної влади.

25. Основна сучасна криза людини пов'язується з тим, що ми, відчуваючи певний дискомфорт в існуючому «онто», за допомогою гомогенізації прагнемо виступити геометром нової, більш зручної для неї реальності, «втікши» у своїй самоурбанізації від існуючої природної дійсності в штучно створений нами світ.

Чи здатна людина піклуватися про себе самостійно у світі, у якому вона підкорила природу та намагається створити власні правила? Чи не зажене вона себе тим, що відмовляється від природного, туди, звідки немає вороття, тобто в небуття? Нині очевидно, що людина має залишатися сама собою в усіх випадках, як саме це визначено для нас самим буттям, інакше вона перетворюється на інший суб’єкт. Питання про те, чи є місце для такого неприродного переродження (у якому також відсутнє почесне «ложе» для права) у самому «онто», залишається відкритим і риторичним. I не нам його вже вирішувати. Лише дозволимо собі зазначити в цьому плані: не знаходитись у праві - це перебувати поза межами буття, тобто потрапити в юридичне ніщо.

\section{Висновки й перспективи подальших досліджень}

Знову наголосимо, що саме цілісність онтологічної та гносеологічної позицій щодо питань про те, що являє собою право та яким чином воно пізнається, як найбільш повний світоглядний метод вирішення подібних філософських питань дозволило виділити та з'ясувати інші типи проблемних полів існування јus naturale, зафіксувати в осмисленні «тіло» юридичної реальності.

При цьому варто зазначити, що життя - це рух на включеній біговій доріжці, і потрібно постійно рухатись, щоб хоч залишатися на місці. Застій, отже, не має нас влаштовувати. Навколо весь час змінюється світ, такий коловорот змін відбувається й у соціальних відносинах, тому дисбаланс у розвитку пізнання права шляхом зупинення цього процесу $є$ недопустимим. Усе майбутнє нашої юридичної реальності «розігрується» переважно в серцебитті, розумі кожного та загальному життєвому устрої в цілому вже сьогодні. При цьому всім варто пам'ятати, що з універсальної онтогносеологічної позиції лише jus naturale - це те, як має бути зроблено пра- 
вильно в суспільстві. Тому ми проти того, щоб нами керувало «недоправо». Однак виступаємо за те, щоб після стількох поневірянь јus нарешті посіло гідне місце в суспільстві. I лише на праві як єдиному аксіофакторі можна побудувати в нашій державі юридичну реальність, щоб не вступати більше в конфлікт із буттям, у якому живемо. Відтак наш кінцевий лозунг до всіх є таким: «Неістина јus має пасти!»

Одним із перспективних напрямів подальшого дослідження обговорюваної проблеми могло б стати саме точне виявлення фундаментальних рис юридичної реальності, які складають необхідну основу для розвитку всіх існуючих іiі типів і можливого виникнення нових.

Представивши на суд науковості власне вирішення змісту юридичної реальності як суто онтогносеологічного, наполягаємо на тому, що здійснене розкриття сутності цього важливого питання не є єдино правильним методологічним розв'язком усього масиву досліджуваної тематики. Природно, що сьогодні філософські та світоглядні проблеми не мають свого однозначно безумовного варіанта пізнання. Кожна історична епоха вирішує цю проблематику не лише знову, а й по-новому з огляду на відповідні суспільні умови.

Насамкінець нам не залишається нічого, як лише зазначити, що ми вкотре змогли повною мірою пересвідчитись і з усією очевидністю переконатись у важливій тезі: воістину філософія права вважається «пречудовою та чарівною царицею» всіх юридичних наук, яка, надаючи можливість ознайомитись зі своїми дивовижними знаннями про світ јus, заворожує нас відкриттям своїх буттєвих таємниць. У свою чергу ці загадки завжди $€$ «ситною їжею» для глибоких роздумів гурманів-мислителів, виступаючи однією з найкращих «страв» для інтелігібельної душі.

На цьому поки що зупинимось, дякуючи за проявлену увагу до нашої роботи, яка покликана дати старт і стати початком великої розмови, відкрити справжню полеміку з приводу природи юридичної реальності, у якій ми завжди раді взяти участь. Паралельно ми готові вступити в конструктивну дискусію з приводу проведеного нами дослідження й отриманих у ньому результатів.

Eniлог

Сьогодні, коли в нашій державі фактично ведеться неоголошена, проте велика історична війна між темним колоніальним тоталітарним минулим і світлим демократичним європейським майбутнім, надзвичайно важливим є адекватний розгляд такого складного поняття, як «юридична реальність», в аспекті встановлення зв'язку jus та людини. I лише правильна відповідь на це стартове й вузлове питання здатна дати надійний «компас» українському суспільству, відкриваючи, показуючи та освітлюючи єдино правильний шлях до нашого загального спільного добробуту. 


\section{Література}

1. Козловський А.А. Право як пізнання: вступ до гносеології права / А.А. Козловський. Чернівці : Рута, 1999. - 295 с.

2. Котюк I.І. Судова гносеологія: проблеми методології та практики : автореф. дис. ... докт. юрид. наук : спец. 12.00.09 «Кримінальний процес та криміналістика; судова експертиза; оперативно-розшукова діяльність» / I.I. Котюк ; Київський нац. ун-т ім. Т. Шевченка. - К., 2008. - 39 с.

3. Максимов С.И. Правовая реальность как предмет философского осмысления : дисс. ... докт. юрид. наук : спец. 12.00.12 «Философия права» / С.И. Максимов ; Нац. юрид. академия им. Я. Мудрого. - Х., 2002. - 434 с.

4. Цимбалюк М.М. Онтологічні онови теорії правосвідомості : дис. ... докт. юрид. наук : спец. 12.00.12 «Філософія права» / М.М. Цимбалюк ; Київський нац. ун-т внутр. справ. - К., 2009. -408 c.

5. Аверин А.В. Истина и судебная достоверность (постановка проблемы) / А.В. Аверин. СПб. : Издательство Р. Асланова «Юридический центр Пресс», 2007. - 466 с.

6. Гаджиев Г.А. Онтология права: критическое исследование юридического концепта действительности : [монография] / Г.А. Гаджиев. - М. : НОРМА - ИНФРА-М, 2013. - 320 с.

7. Честнов И.Л. Принцип диалога в современной теории права (проблемы правопонимания) : автореф. дисс. ... докт. юрид. наук : спец. 12.00.01 «Теория и история права и государства; история учений о праве и государстве» / И.Л. Честнов ; Санкт-Петербургский юрид. ин-т Генеральной прокуратуры. - СПб., 2002. - 38 с.

\section{А н о т а ц і я}

Бернюков А. М. Основні сучасні положення онтогносеології юридичної реальності. - Стаття.

У статті у світлі сучасної західноєвропейської філософсько-теоретичної думки піддано аналізу основні й загальні методологічні характеристики юридичної реальності.

Ключові слова: право, філософія права, онтологія права, гносеологія права, юридична реальність.

\section{Анн о т а ци я}

Бернюков А. М. Основные современные положения онтогносеологии юридической реальности. - Статья.

В статье в свете современной западноевропейской философско-теоретической мысли подвергаются анализу основные и общие методологические характеристики юридической реальности.

Ключевые слова: право, философия права, онтология права, гносеология права, юридическая реальность.

\section{S u m m a r y}

Bernyukov A. M. Basic modern provisions of onto-gnoseology of legal reality. Article.

In this article, in the light of modern West European philosophical-theoretical thought, the main and general methodological characteristics of legal reality are exposed to the analysis.

Key words: right, legal philosophy, legal ontology, legal gnoseology, legal reality. 